\title{
STATE-OF-THE-ART AND TENDENCIES OF DEVELOPMENT OF EUROPEAN MARKET OF JOINING TECHNOLOGIES (Review of materials of economical-statistical data collection on welding production SVESTA-2014)
}

\author{
O.K. MAKOVETSKAYA \\ E.O. Paton Electric Welding Institute, NASU \\ 11 Bozhenko Str., 03680, Kiev, Ukraine. E-mail: office@paton.kiev.ua
}

\begin{abstract}
Paper gives the research data on volume of production and structure of joining technologies and services in EU countries, received by German Welding Society and European Welding Federation in 2007 and 2010 as well as volume of consumption of welding equipment in EU for 2012 and 2013 and volume of production of welding equipment in Germany in 2012 and 2013. 10 Ref., 13 Tables.
\end{abstract}

$\boldsymbol{K} \boldsymbol{e} \boldsymbol{y} \boldsymbol{w} \boldsymbol{o r d} \boldsymbol{s}:$ European market, welding technologies, welding equipment, joining technologies, volume of welding equipment production

European Union (EU) market of joining technologies (JT) and services, including welding equipment market, makes around $30 \%$ of world market, and the largest EU national market, namely German market, is around $30 \%$ of EU market. Wide-range investigations on evaluation of input of JT in EU economy, carried out in 2007 and 2010 by German Welding Society (DVS) and European Welding Federation (EWF) allowed receiving the most complete evaluation of volume and structure of production as well as EU market of JT and services. Added values and employment level, obtained as a result of JT application [1,2], were also determined.

Investigation of cost volume of JT market in EU countries included evaluation:

- equipment and systems for welding, surfacing, brazing and cutting (including spare parts and accessories), adhesion and mechanical joints, thermal spraying, robots and robotized systems, laser technologies;

- accompanying goods and JT services: materials for welding, surfacing, brazing, coating deposition, adhesives, rivets, gases for welding and cutting, means for environment and individ-

Table 1. Volume of production of equipment and JT systems in the EU in 2007 and 2010

\begin{tabular}{|c|c|c|c|c|}
\hline \multirow{2}{*}{ Joining technologies } & \multicolumn{2}{|c|}{ Production volume, mln Euro } & \multicolumn{2}{|c|}{ Portion, \% } \\
\hline & 2007 & 2010 & 2007 & 2010 \\
\hline Welding and surfacing & $3916^{*}$ & \multirow[t]{3}{*}{3732} & 52 & \multirow[t]{3}{*}{47} \\
\hline Brazing & $629^{*}$ & & 8 & \\
\hline Cutting & $582^{*}$ & & 8 & \\
\hline Spare parts and accessories & - & 2202 & - & 28 \\
\hline Adhesion bonding & 338 & 548 & 5 & 7 \\
\hline Mechanical joining & 324 & 279 & 4 & 3 \\
\hline Thermal spraying & 54 & 59 & 1 & 1 \\
\hline Robots/robotic systems & 323 & 829 & 4 & 10 \\
\hline Laser technologies & 1334 & $301^{* *}$ & 18 & 4 \\
\hline Total & 7500 & 7951 & 100 & 100 \\
\hline
\end{tabular}


INDUSTRIAL

Table 2. Volume of production of accompanying goods and JT services in the EU in 2007 and 2010

\begin{tabular}{|c|c|c|c|c|}
\hline \multirow{2}{*}{ Accompanying goods and JT services } & \multicolumn{2}{|c|}{ Production volume, mln Euro } & \multicolumn{2}{|c|}{ Portion, \% } \\
\hline & 2007 & 2010 & 2007 & 2010 \\
\hline Welding and surfacing consumables & 1717 & \multirow[t]{3}{*}{2027} & 15 & \multirow[t]{3}{*}{27} \\
\hline Materials for brazing & 127 & & 1 & \\
\hline Materials for thermal spraying & 256 & & 2 & \\
\hline Other materials (including adhesives) & 6040 & 1860 & 48 & 25 \\
\hline Welding gases & 2232 & 1728 & 18 & 23 \\
\hline Rivets & 500 & 552 & 4 & 7 \\
\hline Means for environment and individual protection & 277 & 267 & 2 & 4 \\
\hline Vent equipment & 50 & - & 1 & - \\
\hline Control means & 723 & 688 & 5 & 9 \\
\hline Education & 561 & 417 & 4 & 5 \\
\hline Total & 12,483 & 7539 & 100 & 100 \\
\hline
\end{tabular}

ual protection, control means, equipment for vent systems, education.

Data, obtained as a result of investigations in a period of 2007-2010 and statistical data on volume of welding equipment production in Germany in 2012 and 2013, published by DVS, allow evaluating conditions and tendencies of development of JT market and production in EU for 2012 and 2013 [3].

According to research data carried by DVS and EWF the volume of production in EU countries during post-crisis 2010 made 15.5 bln Euro, that is $22.6 \%$ lower than the level of 2007 . Tables 1 and 2 provide for data on volume of production of equipment and systems for separate JT in EU as well as accompanying goods and JT services.

After crisis of 2008, as can be seen from Tables 1 and 2, the growth of equipment production and JT systems was outlined in EU in 2009 as well as significant $(40 \%)$ reduction of volume of production of accompanying goods and JT services took place. Production of JT automation means is growing in EU. Volume of production of robots and robotics complexes rised 2.5 times for three years and exceeded $800 \mathrm{mln}$ Euro in 2010. The International Robotics Federation predicts that volume of sales of industrial robots will increase in Europe by $4 \%$ annually in $2014-$ 2016. At that, it should be noted that portion of welding robots in annual sales had risen from $33 \%$ in 2011 to $50 \%$ in 2013 . Volume of production of equipment for adhesion technologies also increases. Prediction of German experts relatively to rise of this technology application for materials joining was completely proved [4]. Reduction of production volume for accompanying goods took place mainly due to production re- duction in «Other materials» category. Volume of production of materials for welding, surfacing, brazing and thermal spraying in 2010 virtually achieved sales level of 2007. DVS statistical data show $19.4 \%$ increase of production of materials of this category in Germany in 2011, that allows predicting appearance of positive trend in whole for EU during this year [3]. It should also be noted that cost volume of welding consumables in Germany in 2012 and 2013 was reduced for 5 and $6.7 \%$, respectively, and made $550.7 \mathrm{mln}$ Euro in 2013.

Tables 3 and 4 represent data on volume and structure of production of accompanying goods and JT services in 2007 and 2010.

Data given show significant change of structure except for substantial reduction of production volume of accompanying goods and JT services in a period of 2008-2010. Main portion $(\sim 50 \%)$ in structure of production of accompanying goods and services in EU countries in 2007 falls to adhesives production; $18 \%$ - for welding gas; $17 \%$ - materials for welding, surfacing, cutting and thermal spraying. This structure was somewhat different in Germany, i.e. first place on volume of production was taken by welding gas $-28 \%$, the second is the materials for welding, cutting and thermal spraying $(27 \%)$, third is covered by adhesives production (13\%). Services on personnel education made significant portion in EU countries market and, especially, Germany, namely 4.5 and $11 \%$, respectively.

More than 3 times reduction of volume of adhesives production was noted in 2008-2010 in EU, at that its portion in general production volume of accompanying goods and services reduced to $25 \%$. This resulted in change of portion structure of production of accompanying goods 
Table 3. Production of accompanying goods and services in JT field in Germany and the EU in 2007

\begin{tabular}{|c|c|c|c|c|}
\hline \multirow{2}{*}{ Accompanying goods, services } & \multicolumn{2}{|c|}{ Production volume, mln Euro } & \multicolumn{2}{|c|}{ Portion, \% } \\
\hline & Germany & EU & Germany & EU \\
\hline Materials in total, including for: & 576 & 2100 & 27.3 & 16.9 \\
\hline welding and surfacing & 415 & 1717 & 19.7 & 13.8 \\
\hline thermal spraying & 78 & 256 & 3.7 & 2.1 \\
\hline brazing & 83 & 127 & 3.9 & 1.0 \\
\hline Gas for welding and cutting & 598 & 2232 & 28.4 & 17.9 \\
\hline Adhesives & 271 & 6040 & 12.9 & 48.4 \\
\hline Rivets & 134 & 500 & 6.4 & 4.0 \\
\hline Control equipment & 229 & 723 & 10.9 & 5.7 \\
\hline Occupational safety & 49 & 277 & 2.3 & 2.2 \\
\hline Vent equipment & 9 & 50 & 0.4 & 0.4 \\
\hline Education & 241 & 561 & 11.4 & 4.5 \\
\hline Total & 2106 & 12,483 & 100 & 100 \\
\hline
\end{tabular}

Table 4. Production of accompanying goods and services in JT field in Germany and the EU in 2010

\begin{tabular}{||l|c|c|c|c||}
\hline \multirow{2}{*}{\multicolumn{1}{c|}{ Accompanying goods, services }} & Production volume, mln Euro & \multicolumn{3}{c||}{ Portion, \% } \\
\cline { 2 - 6 } & Germany & EU & Germany & EU \\
\hline Materials for welding, surfacing, brazing, thermal spraying & 549 & 2027 & 25.7 & 26.9 \\
\hline Gas for welding and cutting & 544 & 1728 & 25.5 & 22.9 \\
\hline Adhesives & 339 & 1860 & 15.9 & 24.7 \\
\hline Rivets & 182 & 552 & 8.5 & 7.3 \\
\hline Control equipment & 267 & 688 & 12.5 & 9.1 \\
\hline Occupational safety & 56 & 230 & 2.6 & 3.1 \\
\hline Vent equipment & 18 & 37 & 0.8 & 0.5 \\
\hline Education & 179 & 417 & 8.5 & 5.5 \\
\hline Total & 2135 & 7539 & 100 & 100 \\
\hline
\end{tabular}

and services at absence of significant growth of production.

Quantitative volume of welding consumables consumption in EU by estimation of «The Japan Welding News for the World» made 530 thou $t$ or $8.5 \%$ of world consumption of welding consumables in 2013. Consumption of welding consumables reduced by $7 \%$ in EU in 2012 and 2013 based on data of this publication. DVS notes $3 \%$ decrease of production of welding consumables in Germany from 199.7 to 193.6 thou t [3, 5-7] in this period.

Structure of welding consumables consumption in EU included $56 \%$ of solid and $20 \%$ of flux-cored wires. Portion of these materials consumption continues growing, however, this process has become slower. Tables 5 and 6 provide data on volume and structure of consumption of main types of welding consumables in EU and in the world.
Main portion of production volume (more than $70 \%$ ) in the structure of production of equipment and JT systems in EU, based on DVS data, makes equipment and systems for welding, surfacing, cutting and brazing, including spare parts. Table 7 shows the data on production volume of equipment and JT system in EU and Ger-

Table 5. Volume of welding consumables consumption in the world and EU in 2013

\begin{tabular}{|l|c|c|c|c||}
\hline \multirow{2}{*}{ Welding consumables } & \multicolumn{2}{|c|}{ In the world } & \multicolumn{2}{c||}{ In the EU } \\
\cline { 2 - 5 } & thou t & $\%$ & thou t & $\%$ \\
\hline Electrodes & 2389.3 & 100 & 58.3 & 2.4 \\
\hline Flux-cored wire & 863.7 & 100 & 106.0 & 12.3 \\
\hline Wire for SAW & 706.2 & 100 & 68.9 & 9.8 \\
\hline Solid wire & 2324.4 & 100 & 296.8 & 12.8 \\
\hline Total & 6283.6 & 100 & 530.0 & 8.5 \\
\hline
\end{tabular}


INDUSTRIAL

Table 6. Volume and structure of welding consumables consumption in the EU in 2011-2013

\begin{tabular}{|c|c|c|c|c|c|c|}
\hline \multirow{2}{*}{ Welding consumables } & \multicolumn{2}{|c|}{2011} & \multicolumn{2}{|c|}{2012} & \multicolumn{2}{|c|}{2013} \\
\hline & thou $\mathrm{t}$ & $\%$ & thou $\mathrm{t}$ & $\%$ & thou $\mathrm{t}$ & $\%$ \\
\hline Electrodes & 68 & 12 & 60 & 11 & 58 & 11 \\
\hline Flux-cored wire & 108 & 19 & 105 & 19 & 106 & 20 \\
\hline Wire for SAW & 75 & 13 & 77 & 14 & 69 & 13 \\
\hline Solid wire & 319 & 56 & 308 & 56 & 297 & 56 \\
\hline Total & 570 & 100 & 550 & 100 & 530 & 100 \\
\hline
\end{tabular}

many in 2010 for main types of technologies accounting on the basis of costs.

In 2013 cost volume of production of equipment for welding and related technologies (brazing, surfacing, spraying, cutting) in Germany made $1663.8 \mathrm{mln}$ Euro (considering production of spare parts $2430.4 \mathrm{mln}$ Euro), and accounting on the basis of quantities it is 812,088 units. The largest portion, namely, $28 \%$ in the cost structure of production of equipment for welding and related technologies is covered by expensive machines and apparatuses for resistance welding and $27 \%$ in total go for equipment for plastics welding, cutting, laser and ultrasonic welding. At that, their portion is not great accounting on the basis of quantities and makes 1.8 and $5.8 \%$, respectively.

The largest portion in production of equipment for welding and related technologies in Germany accounting on the basis of quantities falls to arc welding - $56.8 \%(461,536$ units $)$, from which equipment for automatic arc and plasma welding makes only $0.5 \%$ (2369 units). At that portion of equipment for automatic arc and plasma welding accounting on the basis of costs makes $8 \%$ and portion of other apparatuses for arc welding, including equipment for
MIG/MAG welding, is $12 \%$. Starting from 2010 , the volume of production of automatic machines for arc welding increased from 336.5 to $464.7 \mathrm{mln}$ Euro in 2013 or by $38 \%$.

Production volume of equipment for welding and related technologies in EU in 2013 can be evaluated on the level of 5 bln Euro and for JT is 10-11 bln Euro based on given above German statistical data and data of Table 7.

Equipment for arc and resistance welding dominate in all world markets, including EU market. Portion of EU in world consumption of welding equipment for arc and resistance welding accounting on the basis of quantities covers $\sim 12 \%$ of equipment for arc welding and $\sim 22 \%$ of equipment for resistance welding according to evaluation of «The Japan Welding News for the World». Portion of equipment for arc welding makes $93 \%$ in the structure of consumption of these types of welding equipment in EU. Tables 8 and 9 provide data on consumption of equipment for arc and resistance welding in the world and EU for 2011 and 2012 accounting on the basis of quantities [8, 9].

The main manufacturers of equipment and accompanying goods and JT services in EU are Germany (as was mentioned above) and Italy,

Table 7. Volume of production of equipment and JT systems in Germany and EU in 2010

\begin{tabular}{|c|c|c|c|c|}
\hline \multirow{2}{*}{ Joining technologies } & \multicolumn{2}{|c|}{ Production volume, mln Euro } & \multicolumn{2}{|c|}{ Portion, \% } \\
\hline & Germany* & $\mathrm{EU}^{* *}$ & Germany & $\mathrm{EU}$ \\
\hline Welding, surfacing, brazing, cutting & 1259 & 3732 & 47.3 & 47.0 \\
\hline Spare parts & 535 & 2202 & 18.6 & 27.6 \\
\hline Adhesion bonding & 309 & 548 & 10.7 & 7.0 \\
\hline Thermal spraying & 17 & 59 & 0.6 & 0.7 \\
\hline Mechanical joining & 89 & 279 & 3.1 & 3.5 \\
\hline Laser technologies & $301^{* * *}$ & $301^{*}$ & 7.9 & 3.7 \\
\hline Robots/robotic systems & 444 & 829 & 15.4 & 10.5 \\
\hline Total & 2881 & 7951 & 100 & 100 \\
\hline $\begin{array}{l}\text { Data for } 2011 . \\
\text { ** Data for } 2010 . \\
\text { Data were provided only by Germany. }\end{array}$ & & & & \\
\hline
\end{tabular}


Table 8. Portion of consumption of equipment for arc and resistance welding in the world and EU in 2012

\begin{tabular}{||l|c|c|c|c||}
\hline \multirow{2}{*}{\multicolumn{1}{c|}{ Welding equipment }} & \multicolumn{2}{c|}{ In the world } & \multicolumn{2}{c||}{ In the EU } \\
\cline { 2 - 5 } & thou un. & $\%$ & thou un. & $\%$ \\
\hline Arc machines & 1301.70 & 100 & 152.5 & 11.7 \\
\hline Resistance machines & 53.85 & 100 & 11.7 & 21.7 \\
\hline Total & 1355.55 & 100 & 164.2 & 12.1 \\
\hline
\end{tabular}

Table 9. Portion of consumption of equipment for arc and resistance welding in the EU in 2011 and 2012

\begin{tabular}{||l|c|c|c|c||}
\hline \multirow{2}{*}{ Welding equipment } & \multicolumn{2}{|c|}{2011} & \multicolumn{2}{c||}{2012} \\
\cline { 2 - 5 } & thou un. & $\%$ & thou un. & $\%$ \\
\hline Arc machines & 150 & 93.2 & 152.5 & 92.9 \\
\hline Resistance machines & 11 & 6.8 & 11.7 & 7.1 \\
\hline Total & 161 & 100 & 164.2 & 100 \\
\hline
\end{tabular}

Table 10. Volume of production of equipment and systems as well as accompanying goods and JT services in the EU in 2007 and 2010 ( $\mathrm{mln}$ Euro)

\begin{tabular}{|c|c|c|c|c|c|c|}
\hline \multirow{2}{*}{ Country } & \multicolumn{3}{|c|}{2007} & \multicolumn{3}{|c|}{2010} \\
\hline & $\begin{array}{l}\text { Equipment and } \\
\text { systems }\end{array}$ & $\begin{array}{l}\text { Accompanying } \\
\text { goods and services }\end{array}$ & Total & $\begin{array}{l}\text { Equipment and } \\
\text { systems }\end{array}$ & $\begin{array}{l}\text { Accompanying } \\
\text { goods and services }\end{array}$ & Total \\
\hline Germany & 2500 & 2110 & 4660 & 2881 & 2135 & 5016 \\
\hline Italy & 1170 & 1800 & 2970 & 876 & 880 & 1758 \\
\hline France & 320 & 1510 & 1830 & 518 & 940 & 1458 \\
\hline Great Britain & 160 & 1190 & 1350 & 213 & 541 & 754 \\
\hline Poland & 97 & 169 & 266 & - & - & - \\
\hline Check Republic & - & - & - & 76 & 51 & 127 \\
\hline Netherlands & 29 & 382 & 411 & 27 & 228 & 255 \\
\hline Other EU countries & 3224 & 5319 & 8543 & 3360 & 2765 & 6125 \\
\hline Total for EU & 7500 & 12,480 & 19,980 & 7951 & 7539 & 15,490 \\
\hline
\end{tabular}

which covers half of production volume and consumption of equipment and accompanying goods and JT services in Europe.

Germany is an indisputable leader of the European market. Only Germany succeeded in recovery of production volume of goods and JT market and intensifying their production during postcrisis period. Data, given in Table 10, allow evaluating regional structure of JT market in EU following from contribution of national economies of EU countries.

Germany and Italy are also the main EU manufacturers of equipment for welding, cutting and brazing. In sum these two countries produce $70 \%$ of all welding equipment in EU (only Germany

Table 11. Volume of production of equipment and systems for welding, brazing and cutting in the EU countries in 2010 (mln Euro)

\begin{tabular}{||l|c|c|c||}
\hline \multicolumn{1}{|c|}{ Country } & Equipment & Spare parts & Total \\
\hline Germany & 1259 & 535 & 1794 \\
\hline Italy & 319 & 255 & 574 \\
\hline France & 137 & 243 & 380 \\
\hline Great Britain & 58 & 99 & 157 \\
\hline Check Republic & 21 & 43 & 64 \\
\hline Other EU countries & 1938 & 1028 & 2966 \\
\hline Total for EU & 3732 & 2202 & 5934 \\
\hline
\end{tabular}

produces around $43 \%$ ). Table 11 provides data on cost volume of production of equipment and systems for welding, cutting and brazing in series of EU countries in 2010.

Investigations, carried by DVS and EWF, showed the relevance of JT for EU economy. In 2010 a total added value, received as a result of JT application, made 65.1 bln Euro in EU for $\sim 1.2 \mathrm{mln}$ of work places. For comparison the total added value, received from JT in 2007 in Europe, was 86 bln Euro at more than $2 \mathrm{mln}$ of work places [1].

Table 12 provides data on quantity of personnel working in the field of production of equipment and systems as well as accompanying goods

Table 12. JT: Quantity of personnel involved in production for the EU and Germany in 2007 and 2010

\begin{tabular}{|l|c|c|c|c||}
\hline \multirow{2}{*}{ Index } & \multicolumn{2}{|c|}{2007} & \multicolumn{2}{c|}{2010} \\
\cline { 2 - 5 } & $\mathrm{EU}$ & Germany & $\mathrm{EU}$ & Germany \\
\hline $\begin{array}{l}\text { Quantity of personnel } \\
\text { working in production of } \\
\text { equipment and JT systems }\end{array}$ & 55,000 & 15,000 & 45,000 & 18,332 \\
\hline $\begin{array}{l}\text { Quantity of personnel } \\
\text { working in production of } \\
\text { accompanying goods and } \\
\text { JT services }\end{array}$ & 68,000 & 15,350 & 36,267 & 16,419 \\
\hline Total & 12,3000 & 30,350 & 81,267 & 34,751 \\
\hline
\end{tabular}


INDUSTRIAL

Table 13. JT application: Quantity of profession-engaged personnel in 2010

\begin{tabular}{||l|c|c|c|c|c|c||}
\hline \multicolumn{1}{|c|}{ Country } & Welders & Other professions & $\begin{array}{c}\text { Operators of } \\
\text { welding robots }\end{array}$ & $\begin{array}{c}\text { Involved in } \\
\text { welding } \\
\text { production, total }\end{array}$ & $\begin{array}{c}\text { Other JT } \\
\text { professions* }\end{array}$ & $\begin{array}{c}\text { Involved in JT, } \\
\text { total }\end{array}$ \\
\hline Germany & 156,146 & 19,611 & 82,570 & 258,327 & 74,157 & 332,484 \\
\hline France & 51,068 & 11,357 & 26,052 & 88,477 & 14,751 & 103,228 \\
\hline Italy & 112,829 & 19,667 & 23,806 & 156,302 & 54,785 & 211,087 \\
\hline Total for the EU & 646,914 & 110,487 & 200,746 & 958,147 & 166,085 & $1,124,232$ \\
\hline $\begin{array}{l}* \\
* \\
*\end{array}$ Snspectors, NDT-inspectors, designers, researchers, instructors, planning engineers. \\
\hline
\end{tabular}

and JT services in EU and Germany for 2007 and 2010.

Number of people working in the branches of industrial production, related with JT application, made 1.1. mln in EU. Table 13 includes data showing quantity of people engaged in welding production fields by their profession for Germany, Italy and France.

Economic crisis 2008 and 2009 had significant effect on European industry including for JT area, and revealed the necessity of its prompt updating. European Committee developed and adopted the plan of post-crisis recovery «Strategy 2020», which is based on new developed program of EU researches and innovations «Horizon 2020» for 2014-2020 with total financing volume $80 \mathrm{bln}$ Euro. The aim of this framework research program is to increase the compatibility of Europe in global meaning, its economic rise and creation of new work places.

Development of progressive joining technologies was also referred to priority directions in scope of EU research and innovation program «Horizon 2020». Realizing the projects in given research direction provides for:
- $20 \%$ reduction of consumption of expensive and critical materials;

- $30 \%$ improvement of technical characteristics of products without increase of its final price;

- increase of automation level and reduction of production time in comparison with currently applied technologies [10].

1. (2009) The economic importance of welding and joining in Europe: Production values, values added and employees. Welding and Cutting, 5, 292-296.

2. (2014) Study shows resilience of joining technology in Europe. Ibid., 1, 8-9.

3. (2014) 2013 - Kein gutes Jahr. Schweissen und Schneiden, 66(9), 500-513.

4. (2005) Neueste Machinery in der Fuegetechnik. Stachlmarkt, 8, 58-59

5. (2014) General description for welding consumables. The Japan Welding News for the World, 67, 4-5.

6. (2013) General description for welding consumables market, Ibid., 63, 4-5.

7. (2012) General description for welding consumables market. Ibid., 59, 5-6.

8. (2011) General description for welding machine's market. Ibid., 55, 5-6.

9. (2013) Worldwide demand for welding machines. Ibid., 64.

10. Horizont 2020. http://www.joining-platform.com

Received 21.04.2015 